\title{
Working Environment and Employment Conditions and their Impact on Skills Shortage in South African Gold Mines
}

\author{
Lumkwana Xingwana ${ }^{1}$, Elroy E Smith ${ }^{2} \&$ Noxolo Eileen Mazibuko ${ }^{2}$ \\ ${ }^{1}$ Sibanye Stillwater Mine, Welkom, South Africa \\ ${ }^{2}$ Department of Business Management, Nelson Mandela Metropolitan University, South Africa \\ Correspondence: Lumkwana Xingwana, Sibanye Stillwater Mine, Welkom, South Africa. Tel: 27-725-017-964.
}

Received: December14, 2018; Accepted: January 14, 2019; Published: January 31, 2019

The research is personally financed (Lumkwana Xingwana).

\begin{abstract}
The purpose of the study was to examine the direct relationship and effect of human resource management practices (working environment and employment conditions) on perceived skills shortage among engineers, professionals, and supervisors in the South African gold mines. A sample of 300 engineers, professionals and supervisors was selected by purposive sampling from three selected South African gold mines. For the analysis of the data collected through a self-administered questionnaire, correlation and multiple regression were conducted using Social Package for Social Sciences, version 25. The study revealed that the working environment and employment conditions had a positive significant relationship with the perceived skills shortage in the gold mines. Considering the regression coefficients of two predictors, working environment exerted a greater impact on perceived skills shortage than employment conditions. The benefits of providing an attractive employment condition and supportive working environment create incentives for job satisfaction, employee's intention to stay and talent retention. The study contributes to the growing research of skills shortage by conducting empirical tests consisting of three variables (perceived skills shortage, working environment, and employment conditions) in the gold mining context.
\end{abstract}

Keywords: working environment, employment conditions, perceived skills shortage, gold mines

\section{Introduction}

Pressure from skills shortage had abated in the current South African gold mining environment. The reason for the decline is due to a large number of unpredictable variables influencing demand such as retrenchments, costreduction exercises, delay or cancellation of new projects and a number of mine closures (Ernst \& Young, 2014, p. 38). Consequently, the skills shortage is no longer a universal concept across the sector but a matter of balancing (people - technology, flexibility - routines and pace - presence) the ever-increasing skill requirements (Skjerve \& Simeo, 2018, p. 6). Skill balance requires significant investment in people and start training them now for the skills that will be required in the future (Ernst \& Young, 2014, p. 37). The three mining companies surveyed have inhouse training centers, learnership programmes and supporting the development of staff through sponsorships, bursaries and study loans. Although training programmes have improved, skills shortage in frontline and supervisory positions is still being blamed for not achieving the mining targets (safety, quality, output, and reduced costs) as experienced personnel retire or leave the company (Moraka \& Jansen van Rensburg, 2015, p. 671; Musingwini, Cruise, \& Phillips, 2012, p. 941). However, mining companies find it very difficult to attract and retain these skilled employees as they compete for scarce skills with infrastructure, manufacturing and other local industries. They are at a disadvantage due to harsh conditions, remote locations and long working hours in which they operate (Lane, Guzek \& Van Antwerpen, 2015, p. 475; Moraka \& Jansen van Rensburg, 2015, p. 676).

It is increasingly evident that human resource management practices (working environment and employment conditions) will continue to be a critical component of skills shortage in the South African gold mines. The human resource management practices - skills shortage interactions are expected to be an important criterion for the success and sustainability of the gold mines. Several researches have been conducted on the influence of working environment and employee compensation/ pay/ rewards on job satisfaction (Bakotić \& Babić, 2013; Malik, Danish \& Munir, 2012; O'Donnell \& Mirtcheva-Broderson, 2015); employee's intention to stay (Guchait \& Cho, 2010; 
Markey, Ravenswood \& Webber 2012) and employee retention (Msengeti \& Obwogi, 2015; Rumman, Jawabreh, Alhyasat \& Hamour, 2013). However, few studies explored the impact of the working environment and employment conditions on skills shortages within the mining industry - known for being tough and a hazardous occupation (Masia \& Pienaar, 2011, p. 2). Worldwide, mining is inherently dangerous work with a record of recurring accidents (fatalities and occasional disasters) and high incidences of occupational disease, undertaken in a remote setting and long hours (Malherbe, 2000:24; Masia \& Pienaar 2011, p. 1).

\subsection{Problem Statement}

The continuing proliferation of labour disputes and the unwarranted safety stoppages tarnish the image of the industry (Antin, 2013, p. 1; Bohlmann, Dixon, Rimmer \& Van Heerden, 2014, p. 1) and this conveys the need for research that extends beyond the dynamic nature of the mine into the effect of both the working environment and employment conditions on skills shortage in the mining industry. The need can be illustrated in many ways. Workers have to work kilometers underground in dark, narrow, confined spaces with high temperatures and humidity (Research Focus 2007, p. 8). High temperatures and humidity create difficult working conditions. In addition to the working conditions, at the time of writing this article, the National Union of Mineworkers at Goldfields South Deep halted the mine for 45 days (ended on the $18^{\text {th }}$ of December 2018) protesting against the retrenchments (Webb 2018), while wage and benefits strike at Sibanye Stillwater gold mines entered its second month, with billions of Rand in lost production, unpaid wages, three lives and many employees injured. There was no sign of an impasse between Sibanye Stillwater and AMCU as at the $28^{\text {th }}$ of January 2019. Hence a good image of the gold mining sector was not portrayed.

The mining managers are facing a challenge to develop an understanding of the working environment and employment conditions so that they can implement structures that would attract, develop and retain skilled employees (Lane et al., 2015, p. 475). However, the dynamic nature of the mine - depth and temperature, increasing costs of mining at a depth, minerals being limited, irreplaceable and only found in specific areas - has become increasingly challenging to balance the skills required for sustainable development.

\subsection{The Objectives of the Study}

The objectives of the study are the following:

- To examine the relationship between working environment, employment conditions and perceived skills shortage in the South African gold mines.

- To explore the impact of both the working environment and employment conditions on perceived skills shortage in the South African gold mines.

The rest of the paper is structured as follows: First, the relevant literature is reviewed and hypotheses are developed. This is followed by a discussion of the research methods and procedures used in this study. Finally, the overall discussion of the findings, implications, and recommendations are presented.

\section{Literature Review and Hypothesis Development}

\subsection{Perceived Skill Shortages}

Perceived skills shortage concerns the extent to which employees perceive mine working conditions as the contributing factors to the skills shortage in the gold mines. Skills shortage can be defined as a situation in which employers are unable to fill vacancies in a specific occupation or specialisation due to an insufficient number of workers with the required qualifications and experience (Green, Machin \& Wilkinson 1998, pp. 165-187). An attempt to conceptualise skill shortages is by examining push and pull factors (Rasool, Botha \& Bischoff, 2012, p. 11). Push factors are negative aspects of the workplace stimulating employees to consider leaving the organisation, for example, poor working environment, lack of employee engagement and autonomy. Pull factors are positive factors that draw employees towards the organisation, for example, attractive salary packages, promotion prospects and work-life balance (Jauhar \& Yusof, 2011, p. 121). Barnow, Trutko and Lerman (1998, p. 7) define skills shortage as the market disequilibrium between supply and demand in which the number of workers demanded exceeds the supply available and willing to work at a particular wage and working conditions at a particular place and point in time.

\subsection{Relationship between Working Environment and Skills Shortage}

The working environment is a complex, multidimensional phenomenon with numerous antecedents that can include the physical setting, psychosocial and organisational features of the work itself (Markey et al., 2012, p. 4). The psychosocial environment refers to the characteristics of the job itself such as workload, task complexity and employee health and safety (Wiskow, Albreht \& de Pietro, 2010, p. 6). Organisational features include broad 
features of the work such as organisational culture and history. The physical environment includes tangible components of the workplace environment such as high temperatures, fumes, dust, intensive noise, harmful gases, design and construction of the workplace, and workplace policies and procedures. This can be illustrated by the number of fatalities and injuries caused by slippery surfaces, caving in of side-walls, struck by an object, or hurt by machinery (Emery, 2005, p. 28). Although mine health and safety conditions have improved dramatically, fugitive dust and fumes generated during drilling and blasting operations and mine tailing facilities place people at risks of developing either tuberculosis, pneumoconiosis or silicosis (Ololade, 2012, p. 9). Awases, Gbary, Nyoni, and Chatora (2004, p. 54) assert that the working environment has been singled out along with remuneration, as one of the major de-motivators and are often the reason why skilled people leave their occupation. Vermaak (2010, p. 52) believe that the main reason for skills shortage is the lack of a professional working environment where employees may grow, be better professionals and have a sense of fulfillment. According to the Al-Anzi $(2009$, p. 3) and Kingsley $(2012$, p. 25$)$, the quality of the workplace environment mostly impacts on the level of employees' motivation, the extent of their error rate, absenteeism and how long they are going to stay with the organisation. However, according to Markey et al. (2012, p. 18), the working environment has a statistically significant impact on employees' intention to quit in workplaces perceived as having been a good workplace environment. The argument of this study is that these issues are not statistically significant in influencing employees' intention to quit if employees perceive that their work is physically demanding and dangerous, like mining. Based on the aforementioned discussions, it is hypothesised that:

$\mathrm{HO}^{l}$ : The working environment has no significant relationship with perceived skill shortages in South African gold mines.

\subsection{Relationship between Employment Conditions and Skills Shortages}

Employment conditions refer to those matters that define the essential aspects of the contract of employment or employment relationship (Eurofound, 2010). In terms of the Basic Conditions of Employment Act (BCEA) 75 of 1997, there must be a contract of employment whenever a relationship between employer and employee exist. This contract consists of the number of terms some of which are expressed terms (rate of pay, hours of work; leave periods, disciplinary rules), some implied terms (discrimination in terms of race, gender, disability) and statutory regulation of employment (Van Jaarsveld, 2008, p. 13). It is procedurally fair that when an employer wishes to change the employment conditions an employee must be consulted and agreement sought (Barnard, 2012, p. 24). If no agreement is reached a dispute may be declared, inciting unions to strike and forcing employers to lock workers out, dismiss workers for operational requirements and unitarily implement the changes. The consequence of not agreeing are huge and expensive in the mining industry, as platinum mines found out in 2014 after wildcat strikes (Bohlmann, et al., 2014, p. 1). The remote locations of some sites, such as offshore oil rigs and some mines, require employees to actually live on-site for weeks at a time, often working long hours, followed by an extended leave period on-shore (Singh, 2007, p. 1). Colley (2005, p. 1) cited the biggest problem in mining in terms of attracting and retaining skilled employees as working hours, followed by remote locations. These long hours lead to (amongst other issues) fatigue, depression, and work-stress. Potter, Deshields, Divanbeigi, Berger, Cipriano, Norris and Olsen (2010, p. 57) believed that compassion fatigue can take a toll on the mining professional, causing decreased productivity, more sick days used and higher employee turnover. On the other hand, Chew and Chan $(2008$, p. 5) state that financial and nonfinancial rewards are the most critical issues in terms of attracting and retaining talent. The talented and skilled employees tend to choose an organisation based on the benefits package, salaries, and learning and development opportunities offered (Florea \& Mihai, 2014, p. 302). As a result, some organisations may even provide remuneration packages that are well above the market rate to attract and retain critical talents that often include special pay premiums, allocating shares or bonuses. Pay is an important consideration for most employees in accepting a job, and unfair pay can be a strong de-motivating factor. However, after people have settled down in a job, extrinsic rewards become less important as day-to-day motivation is more strongly driven by intrinsic rewards (Ram \& Prabhakar, 2011, p. 50). It is, therefore hypothesised that:

$\mathrm{HO}^{2}$ : Employment conditions have no significant relationship with perceived skill shortages in South African gold mines.

Based on the literature review and discussions above it was possible to construct the hypothesis model of this study as seen in Figure 1. 


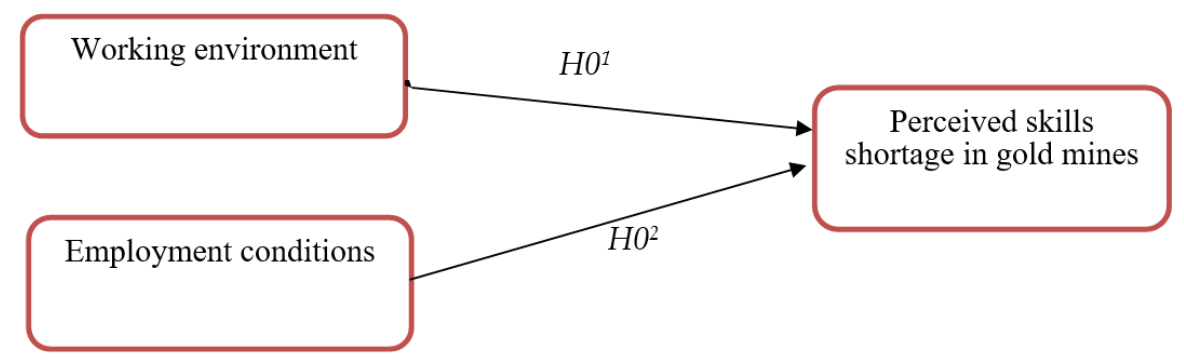

Figure 1. Hypothetical model of the influence of the working environment and employment conditions on perceived skills shortage in gold mines

Source: Own construction

The simple multiple regression in Figure 1 above, describes how perceived skills shortage (Y) depends linearly on the working environment (X1) and employment conditions (X2) in the South African gold mines. Thus, the equation model of multiple regression analysis used in this research was formulated as follows:

$$
\mathrm{Y}=\beta 0+\beta \mathrm{X} 1+\beta \mathrm{X} 2
$$

While $\beta 0$ represents the controlled variables and other factors not mentioned in this model

\section{Research Methodology}

\subsection{Research Design}

The study was correlational in nature with cause and effect approach. A correlation research design is useful for explaining the nature of the relationships between working environment, employment conditions and perceived skills shortage that can be used for making predictions (Welman, Kruger \& Mitchell 2005, p. 6).

\subsection{Participants}

The non-probability purposive sampling method was applied in selecting the participants from three South African gold mines. Leedy and Ormrod (2005) define purposive sampling as selecting participants based on certain characteristics. The characteristics of the sample were that they are all skilled employees working in the South African gold mines, are relevant to the topic and can provide the best information to achieve the objective of the study. A total of 300 supervisors, engineers and professionals participated in this study, which composed of 263 $(88 \%)$ male, mainly Africans $(n=210)$ and $54 \%$ were in the age group of $41-60$ years. Sixty-eight percent of the respondents were supervisors and artisans, while fifty-six percent $(n=167)$ have either completed their Grade 12 or lower and only 10 of the participants were Bachelor degree holders. The study obtained a sample size of 300 compared to the minimum sample size of 150 as suggested by Van Voorhis and Morgan (2007, p. 49), as such the minimum requirement for further analysis was met.

\subsection{Data Collection}

The primary data was collected using a structured self-administered questionnaire, consisting of three sections. Section A entailed general perceptions regarding factors influencing skills shortage, that is workplace environment and employment conditions in the gold mining sector. Section B was designed to obtain information relating to perceptions in respect of skills shortages in the gold mining sector. Section $\mathrm{C}$ included questions about the biographical characteristics of the respondents, using the nominal scale. The initial questionnaire was pilot-tested among 30 supervisors, engineers and professionals from the designated population to determine any problem areas. Suggestions were used to improve the measuring instrument. Out of 343 questionnaires administered only 300 were usable and subjected to further statistical analyses, resulting in an $87 \%$, response rate.

\subsection{Measures}

The questionnaire consisted of 32 items (questions) excluding demographics, which asked the respondents to indicate a degree of agreement and disagreement with each of the statements regarding perceived skills shortage, working environment and employment conditions in their organisation, using a seven-point Likert-type scale with ordinal characteristics. A seven-point Likert-type scale refers to responses from "Strongly Agree - 7, Agree and Agree Somewhat", 'Neutral' to "Disagree Somewhat, Disagree, Strongly Disagree - 1" with a middle point being "Neutral - 4". 
Working environment scale (WES): The WES was a 10-item scale which was designed to measure the perception regarding the working environment in the organisation. Respondents were invited to rate their perceptions on a seven-point Likert-type scale. Items were divided into five subscales; health and safety awareness (4 items), worklife balance (2 items), supervisor and co-worker's relationships ( 2 items), workplace temperature and noise appropriateness (1 item) and equipment and machinery availability (1 item). The initial Cronbach's alpha for this scale in the current study was 0.806 .

Employment conditions scale (ECS): The ECS was a 12-item scale which was designed to measure the perception regarding employment conditions within the organisation. Respondents were invited to rate their perceptions on a seven-point Likert-type scale. Items were divided into the employment contract, regulated wage rates and overtime payment, working hours, allowances (sick leave, maternity leave, and housing) and provision of a contributory retirement and medical aid cover. Each item was rated using a seven-point Likert-type scale. The initial Cronbach's alpha for this scale in the current study was 0.889 .

Perceived skills shortage test (SSC): The third measure, perceived skills shortage, consisted of 10 items meant to measure the perception of skills shortage in the organisation. Respondents were invited to rate their perceptions on a seven-point Likert-type scale. Some of the items were; 'there is a shortage of skilled employees', 'apprentices/ trainees leave on completion of their training', 'experienced staff has/ about to retire', and 'increased automation/ technology requires the high level of technical skills'. The initial Cronbach's alpha for this scale in the current study was 0.642 , which was not acceptable.

Tabachnick and Fidell (2019) and Field (2013) recommended the use of at least 10 to 15 items per scale, hence the study can be considered to have met one of the minimum requirements of further analysis.

Demographic scale: The fourth section consisted of items meant to determine a respondent's gender, age, qualifications, occupation position and length of tenure. A significant relationship may exist between demographic factors and perceived skills shortage and so they were controlled. For instance, Al Mamun and Hasan (2017: 63) claimed that female employees are more likely to quit as compared to male employees. Their unchanging state would allow the relationship between human resource management practices (working environment and employment conditions) and perceived skills shortage to be purified, uncovered and better understood (Bernerth \& Aguinis 2016: 230).

\subsection{Data Analysis Techniques}

The study generated quantitative data. The data obtained using the questionnaire was edited and coded and then analysed with Social Package for Social Sciences (SPSS), Version 25. The hypothetical model of the study was tested using correlation and regression analysis

\section{Empirical Results}

\subsection{Descriptive Statistics of Data}

The descriptive statistics were used to explore the data, based on a seven-point rating scale ranging from 'Strongly Disagree -1 ', 'Neutral -4 ' to 'Strongly agree -7 '. Table 1 below provides the descriptive statistics.

Table 1. Descriptive statistics of research variables

\begin{tabular}{|c|c|c|c|c|c|}
\hline Factor & $\mathbf{N}$ & Mean & Std. Dev. & Skewness & Kurtosis \\
\hline Working environment (WE) & 300 & 4.66 & 1.089 & $-0,155$ & $-0,448$ \\
\hline Conditions of employment (EC) & 300 & 4.87 & 1.134 & $-0,788$ & 0,105 \\
\hline Perceived skill shortages (SS) & 300 & 4.57 & 1.296 & $-0,609$ & 0,007 \\
\hline
\end{tabular}

Source: Authors' calculation

In Table 1, the mean score of respondents regarding the working environment, conditions of employment and perceived skills shortage were $4.66,4.87$ and 4.57 , respectively. This indicates that respondents tended to have answered above the middle of the range and very close to 'agree somewhat'. Therefore, the respondents were of the view that human resource management practices (working environment and conditions of employment) are somehow in place and satisfactorily applied. The skewness statistic values $(-0,155,-0,788$ and $-0,609)$ and kurtosis statistic values $(-0,448,0,105$ and 0,007$)$ of WE, EC and SS, respectfully, were in the range of -2 to +2 and according to Hair et al. (2010, p. 73), and Pallant (2007, p. 56) the data were normally distributed. 


\subsection{Reliability Test}

The Cronbach's alpha is a measure of internal consistency of the scale, for which the values greater than 0.7 had good reliability (Downing 2004; Nunnally 1978). The Cronbach's values of three measuring instruments are presented in Table 2.

Table 2. Cronbach's alpha values of measuring instruments

\begin{tabular}{lcccc}
\hline Measuring instruments & Initial items & Initial values & Final items & Final values \\
\hline Working environment & 10 & 0.806 & 8 & 0.824 \\
Employment conditions & 12 & 0.889 & 11 & 0.891 \\
Skills shortages & 10 & 0.642 & 3 & 0.712 \\
\hline
\end{tabular}

Source: Authors' calculation

Table 2 shows that all measuring instruments had good reliability, with Cronbach's alpha values greater than 0.7 in the final stage. One can see from Table 1 that if those items that had item-total correlation scores of less than 0.5 , were deleted Cronbach's alpha increased.

\subsection{Validity Test}

To assess the suitability of construct items and factorability of the data, two statistical measures were used. They are the Kaiser-Meyer-Olkin (KMO) measure of sampling adequacy and Bartlett's test of sphericity. The results of the KMO and Bartlett's test are presented in Table 3.

Table 3. KMO and Bartlett's test of inter-item correlation

\begin{tabular}{lcccc}
\hline Variable & KMO & Approx. Chi-Square & Df & Sig. \\
\hline Working environment (WE) & 0.829 & 836.777 & 45 & 0.0000 \\
Employment conditions (EC) & 0.911 & 1437.338 & 66 & 0.0000 \\
Perceived skills shortage (SS) & 0.663 & 459.877 & 45 & 0.0000 \\
\hline
\end{tabular}

Source: Authors' calculation

As evidenced in Table 3 above, the KMO values for working environment, employment conditions, and perceived skills shortage were above the commonly recommended value of 0.6 (Pallant, 2010). Barlett's test of Sphericity for all variables was sufficiently large and statistically significant at $\mathrm{p}<0.05$. Therefore, the sample and data of 32 items were adequate and suited for factor analysis to be performed in order to achieve the objective of the study.

\subsection{Exploratory Factor Analysis}

The main purpose of exploratory factor analysis was to assess the reliability of each of the factors and reduce a large set of data into a small and manageable bundle of factors. This was achieved through the application of the Principal Component Analysis (PCA) by varimax rotation with Kaiser Normalisation to find out the dominant components, eigenvalue greater than 1 and factor loading of above 0.5 , for a working environment, employment conditions and perceived skills shortage. Table 4 presents a summary of Eigenvalues and variance explained.

Table 4. Results from factor analysis for WE, EC and SS scales

\begin{tabular}{clllll}
\hline $\begin{array}{c}\text { Variable: } \\
\text { Round }\end{array}$ & Eigenvalue & $\begin{array}{l}\text { Variance } \\
\text { Explained \% }\end{array}$ & Items (accepted) & Cronbach's alpha & $\begin{array}{l}\text { Items } \\
0.5)\end{array}$ \\
\hline WES: 1 & $3.867 \& 1.272$ & 51.383 & 10 & 0.806 & 2 \\
2 & 3625 & 45.308 & $(8)$ & 0.824 & 0.889 \\
ECS: 1 & $5.479 \& 1.192$ & 55.589 & 12 & 0.891 & 1 \\
2 & 5.314 & 48.309 & $(11)$ & 0.642 & 7 \\
SSC: 1 & $2.493,1.707,1.101 \& 1.044$ & 63.446 & 10 & 0.722 & \\
2 & 2.100 & 52.495 & $(3)$ & & \\
\hline
\end{tabular}

Extraction method: Principal Component Analysis; Rotation method: Varimax with Kaiser Normalisation

Source: Authors' calculation 
The results from table 4 show that all variables were initially multidimensional in round 1 . Two factors $(3.867 \&$ 1.272) for working environment, two factors $(5.479 \& 1.192)$ for conditions of employment and four factors (2.493, $1.707,1.10 \& 1.044)$ for perceived skills shortage which had an eigenvalue of greater than one and the good level of reliability $(0.642<\alpha<0.889)$, were extracted. Initial examination of the component matrix of three variables found 10 components, which were below 0.5 and had to be dropped for further analysis. The PCA had to be rerun with the retained components, hence the new results are presented in round 2.

Factor 1 - Working environment: Initial examination of component matrix found that component 6 (adequate restroom and cafeteria) and component 7 (layout and placement of equipment) had an item-total correlation score of less than 0.5 and had to be dropped. hence there was a need to repeat the test. The eight retained components loaded significantly on one factor $(0.527<\mathrm{r}<0.736)$ with a good level of reliability $(\alpha=0.831)$. The WES was found to be unidimensional with a single component in extraction sums of squared loadings section emerging with an eigenvalue greater than 1 (eigenvalue $=3.625$; variance explained $=45.308 \%$ ). This means that the perception of the working environment among supervisors, engineers and professionals was explained by eight extracted components, suggesting that WEC measured what it was intended to measure.

Factor 2 - Employment conditions: Initial examination of component matrix found that component 8 (employment contract) had an item-total correlation score of less than 0.5 and had to be dropped, hence there was a need to repeat the test. The eleven retained components loaded significantly on one factor $(0.580<\mathrm{r}<0.764)$ with a good level of reliability $(\alpha=0.891)$. The ECS was found to be unidimensional with a single component in extraction sums of squared loadings section emerging with an eigenvalue greater than 1 (eigenvalue $=5.314$; variance explained $=48.309 \%$ ). This means that the perception of employment conditions among supervisors, engineers and professionals was explained by eleven extracted components, suggesting that ECS measured what it was supposed to measure.

Factor 3 - Perceived skills shortage: Initial examination of the factor matrix found that only three items had itemtotal correlation scores of more than 0.5 and had to be retained. These items were item 3 (many trained and experienced miners had sought greener pastures in other industries), 6 (the location of the mines is conducive to attract scarce skilled labour) and 8 (experience staff has/ about to retire). According to Johari, Yahya and Omar (2011: 140), a cut-off line of three items with high loadings may be used as the threshold to ensure practical significance. In Table 4, PCA for SSC was rerun and rotated on the new three-component scale and the components loaded significantly on one factor $(0.565<\mathrm{r}<0.807)$ with an acceptable level of reliability $(\alpha=0.712)$. The SSC was found to be unidimensional with a single component in rotation sums of squared loadings section, emerging with an eigenvalue greater than 1 (eigenvalue $=2.100$; variance explained $=52.495 \%$ ). This means that the common variance shared by three rotated components can be accounted for by one factor labelled perceived skills shortage.

These statistical results confirmed the reliability and validity of measurement scales used for this study, hence it is appropriate to continue further with data analysis.

\subsection{Checking the Assumptions of Multiple Regression Analysis}

It is important that the relationship between perceived skills shortage and both the working environment and employment conditions should satisfy certain assumptions, for the sake of accurate, unbiased and consistent estimation of the research results. Osborne and Waters (2002) suggested four assumptions of multiple linear regression, namely linearity, normality, homoscedasticity, and multicollinearity.

Linearity: The linear relationship may be explained fairly by visually inspecting the scatterplot for linearity. The scatterplot in Figure 2(b) showed a positive linear relationship between the WE and SS and EC and SS since there were increasing patterns exhibited in the graph. Thus, the assumption of linearity was not violated.

Normality: The assumption of normality was assessed using the histogram in Figure 2(c) and normal probabilityprobability plot (P-P plot) in Figure 2(a), both of which indicate that the data is normally distributed. In Figure 2(a), the observed residue values lie closer to normality line (45 degrees) which represents the true normal distribution. With these results, the data of all study variables did not violate the normality assumption.

Homoscedasticity: The assumption of homoscedasticity was assessed using a standardized residual scatterplot in Figure 2(b). The graph shows that the variance of the composite score of the dependent variable of SS was homogenous across the two independent variables of WE and EC. Similarly, the residual scatterplot shows that the errors are spread out consistently around the regression line between the variables, hence the study met the assumption of homoscedasticity. 


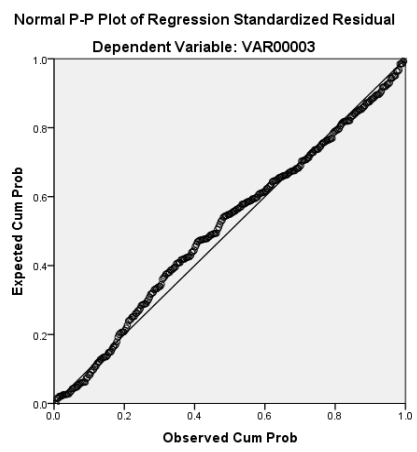

Figure 2(a)

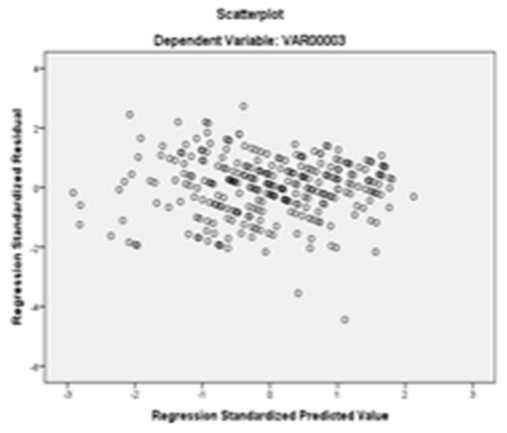

Figure 2 (b)

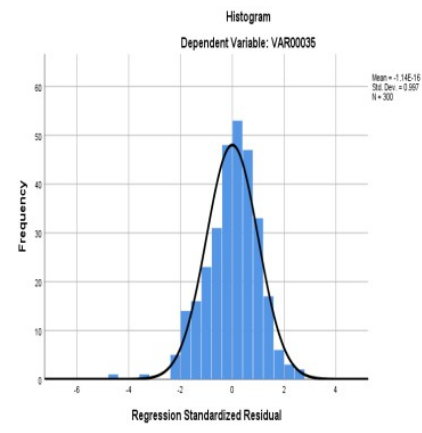

Figure 2 (c)

Figure. 2. Assessing the assumption of linearity, normality, and homoscedasticity

Source: Authors' processed data

Multi-collinearity: The results of a multi-collinearity test in Table 8 show that there was no evidence of multicollinearity between two predictors as the Variance Inflation Factor (VIF) value of 2.174 was less than 10 and Tolerance score of 0.460 lied above 0.1 as suggested by Field, (2013).

Since the assumptions of normality, linearity, multi-collinearity, and homoscedasticity were found not to have been violated, it was appropriate to conduct correlation and multiple linear regression to achieve the purpose of the study, that is, hypothesis testing.

\section{Findings and Hypothesis Testing}

Two hypotheses were formulated and tested using correlation (r) and regression ( $\beta$ ) coefficients while the slope and 5\% level of significance were criteria used for accepting and rejecting the null hypotheses.

\subsection{Pearson Correlation Analysis}

Pearson correlation analysis was conducted on the data to examine the direction and strength of the bivariate relationship between working environment, employment conditions, and perceived skills shortage. The results of correlation analysis are presented in Table 5 below.

Table 5. Pearson correlation of variables

\begin{tabular}{lllll}
\hline Variables & N & WE & EC & SS \\
\hline Working environment (WE) & 300 & 1.000 & & \\
Employment conditions (EC) & 300 & $0.734^{* *}$ & 1.000 & \\
Perceived skills shortage (SS) & 300 & $0.622^{* *}$ & $0.534^{* *}$ & 1.000 \\
\hline
\end{tabular}

** = correlation is significant at the 0.01 level (2-tailed)

Source: Authors' calculation

The results show that working environment with $r=0.622, \mathrm{p}<0.01$ has a positive and strongest correlation with perceived skills shortage than employment conditions $(r=0.534, \mathrm{p}<0.01)$. Furthermore, the working environment and employment conditions are not highly correlated to each other as $r=0.734$ with $\mathrm{p}<0.01$ is well below the 'rule of thumb'. The 'rule of thumb' suggests that excessive collinearity may be present in subsequent stages of the multiple regression analysis when the correlation coefficient is 0.8 and above (Argyrous, 2011, p. 272; Meyers, Gamst \& Guarino, 2013, p. 364). This means the construct items of WE and EC provide the information which is not given by the construct items of one another. All variables were positive and moderately inter-correlated, indicating a change in the same direction.

\subsection{Regression Analysis}

Multiple regression analysis was conducted to identify the best predictors of the perceived skills shortage and to show the proportion of variance in the perceived skills shortage explained by working environment and employment conditions. Table 6, 7 and 8 below display the goodness of Fit, ANOVA testing and regression coefficients results. 
Table 6. Testing the goodness of Fit

\begin{tabular}{|c|c|c|c|c|c|}
\hline Path & Observations & $\mathbf{R}$ & R-square & Adjusted R square & Standard Error \\
\hline WE & & & & & \\
\hline $\begin{array}{ll}\mathrm{EC} & \mathrm{SS} \rightarrow\end{array}$ & 300 & 0,632312712 & 0,399819365 & 0,395777745 & 1,0075318 \\
\hline
\end{tabular}

Source: Authors' calculation

Table 6 indicates that the regression model poorly fits in explaining perceived skills shortage. This was supported by a positive and moderate coefficient of multiple correlations of $\mathrm{R}=0.6323$ and coefficient of determination of $\mathrm{R}^{2}=0.3998$. The coefficient of determination indicates that $39.98 \%$ of the variation in perceived skills shortage is due to the change in two predictors (WE and EC) while controlling the effects of gender, age, qualifications, occupation position and length of tenure.

Table 7. ANOVA testing

\begin{tabular}{lccccc}
\hline & Df & SS & MS & F & Significance F \\
\hline Regression & 2 & 200,8426 & 100,4213 & 98,9255 & 0.0000 \\
Residual & 297 & 301,4907 & 1,0151 & & \\
Total & 299 & 502,3333 & & & \\
\hline
\end{tabular}

Source: Authors' calculation

Based on Table 7, the ANOVA testing obtained statistically significant of 0.0000 which is less than 0.05 . This means the two dimensions (working environment and employment conditions) of human resource management practices simultaneously influence perceived skills shortage in the gold mines.

Table 8. Regression coefficients: human resource practices and perceived skills shortage

\begin{tabular}{lllllll}
\hline \multirow{2}{*}{ Model } & \multicolumn{3}{l}{ Unstandardized Coefficients } & & \multicolumn{3}{l}{ Collinearity Statistics } & Hypothesis results \\
\cline { 2 - 5 } \cline { 5 - 7 } B & Std. Error & Sig & & Tolerance & VIF & \\
WE & 0.8671 & 0.2744 & 0.0017 & & & \\
EC & 0.5942 & 0.0787 & 0.0000 & 0.462 & 2.166 & $\mathrm{H}^{1}$ is rejected $(+): \mathrm{S}$ \\
\hline
\end{tabular}

Source: Authors' calculation

The results in Table 8 reveal that the working environment and employment conditions have a significant impact on perceived skills shortage at $p<0$. 05. Therefore, the unstandardized beta coefficients as shown in Table 8 explains the gradients of the regression formula which is presented below as follows:

Perceived skills shortage $=0,8671+0.5942(\mathrm{WE})+0.1908(\mathrm{EC})$.

This formula can be explained by the following two hypotheses. The first hypothesis was formulated to determine the respondent's views of whether there is a relationship between working environment and perceived skills shortage in the gold mines in relation to health and safety awareness, work-life balance, supervisor and co-worker's relationships, workplace temperature and noise appropriateness and equipment and machinery availability. The null hypothesis was stated below.

$\mathrm{HO}^{l}$ : The working environment has no significant relationship with perceived skill shortages in South African gold mines.

It was proven in Table 5 that the working environment has a moderate and positive linear correlation with perceived skills shortage with $r=0.622$ at a significance level of 0.01 . Furthermore, in Table 8 , the working environment had a significant impact on perceived skills shortage $(\beta=0.5942$ with $p=0,000)$ which is contrary to $\mathrm{H} 0^{1}$. Therefore, there was sufficient and strong evidence that the null hypothesis, $\mathrm{H}^{1}$, was rejected in favour of the alternative hypothesis. This suggests that a unit increase in the working environment while all other relevant 
factors remain constant at $0,8671 \mathrm{Y}$ - intercept, perceived skills shortage will increase by 0.5942 units in South African gold mines.

The second hypothesis was set up to explore the respondents' views of whether there is a relationship between employment conditions and perceived skills shortage in the gold mines in relation to employment contract, regulated wage rates and overtime payment, working hours, allowances (sick leave, maternity leave and housing) and provision of a contributory retirement and medical aid cover. The null hypothesis was stated below.

$\mathrm{HO}^{2}$ : Employment conditions have no significant relationship with perceived skill shortages in South African gold mines.

It was proven in Table 5 that employment conditions $(r=0.534)$ have a moderate and positive linear correlation with perceived skills shortage at a significance level of 0.01 which is contrary to $\mathrm{H}^{2}$. Furthermore, in Table 8 , the working environment had a significant impact on perceived skills shortage $(\beta=0.1908$ with $p=0,000)$ which is contrary to $\mathrm{H}^{1}$. Therefore, there is sufficient and moderate evidence that the null hypothesis, $\mathrm{H}^{2}$, was rejected in favour of the alternative hypothesis. This suggests that a unit increase in employment conditions while all other relevant factors remain constant at 0,8671 Y- intercept, perceived skills shortage will increase by 0.1908 units in South African gold mines.

\section{Discussion and Conclusions}

The study investigated the relationship between the working environment and employment conditions in influencing skills shortage in the South African gold mines. The value of the study is not only that the mine supervisors, engineers, and professionals were selected as samples but it was the first time that working environment, employment conditions, and perceived skills shortage were integrated into one regression model. A regression model indicated $\mathrm{R}^{2}$ of 0.3998 that suggest that 39.98 percent of the variance in perceived skills shortage can be predicted by both the change in the working environment and employment conditions. The other $60 \%$ of the variation could thus be attributed to the controlled variables and other factors not mentioned in this model. These results are consistent with the studies by Tshele and Agumba (2014, p. 102); Peek, Fenard, Gantes and Theiler (2008, p. 24), Musingwini, et al. (2012, p. 939) and Kaplan (2011, p. 18) which reported that there are myriad of factors contributing to the variation in skill shortages. Accordingly, it was hypothesised that working environment and employment conditions would lead to increased level of skills shortage in gold mines.

As predicted, the regression analysis for the eight measures of working environment revealed that statistically working environment is a very strong, positive and significant predictor $(\beta=0.5942, p<0.001)$ of perceived skills shortage in gold mines. These results are consistent with the studies by Msengeti and Obwogi $(2015$, p. 8) and Rumman, et al. (2013, p. 126) postulating that poor working environment has a statistically significant impact on employee turnover in the hospitality industry. Al-Anzi (2009, p. 3) and Kingsley (2012, p. 25) concur with the view in that the quality of the work environment mostly impacts on the level of employees' motivation, the extent of their error rate, absenteeism and how long they are going to stay with the organisation. Therefore, the employees who perceive and feel there are adequacy and appropriateness of various features of the working environment, such as health and safety awareness, supervisor and co-worker's relationships, and workplace temperature, light and noise, employee participation and involvement, will develop positive attitude and behaviour towards their job components. Ultimately, this will lead to less absenteeism, loyal to the organisation, reduction in staff turnover and skills shortage.

On the other hand, the regression analysis for the eleven measures of employment conditions revealed that statistically, terms and employment conditions are moderate, positive and a significant predictor $(\beta=0.1908, \mathrm{p}=$ 0.0121 ) of perceived skill shortages in the gold mines. These results are consistent with the studies by Colley (2005, p. 1) and Chew and Chan (2008, p. 5) who cited working hours, remote locations, financial and nonfinancial rewards as the most critical issues in terms of attracting and retaining talent in the mining industry. Florea and Mihai (2014, p. 302) concur with the view that talented and skilled employees will choose an organisation based on the benefits package and salaries offered. Therefore, the skilled employees who perceive and feel that their performance is rewarded fairly with various features of employment conditions, such as competitive and marketrelated pay, adequate allowances and fringe benefits, flexible short working hours, and performance recognition, are motivated to do their work, increase their performance and stay with the organisation.

Thirdly, the impact of the working environment and employment conditions on the perceived skills shortage differs in magnitude. Considering the Beta values of two predictors, working environment exerts greater impact ( $\beta=$ 0.5942) on perceived skills shortage than employment conditions $(\beta=0.1908)$. The lesser significant impact of employment conditions on perceived skill shortages in the South African gold mines could be attributed to three factors. Firstly, in South Africa, the minimum terms and employment conditions are set in accordance with the 
Basic Conditions of Employment Act (BCEA) 75 of 1997 and at the sectoral level. Secondly, the respondents (supervisors, engineers, and professionals) believed that high salaries are reserved for critical and scarce skills that they occupy in the mining industry. Thirdly, Ram and Prabhakar (2011:50) reported that when people have settled down in a job, extrinsic rewards become less important, as day-to-day motivation is more strongly driven by intrinsic rewards. The greater significance of the relationship between the working environment and perceived skill shortages in the South African gold mines, could be attributed to the fact that mining has inherent risks to health and safety. As a result, maintaining safe and healthy working environment is a key compliance issue for the mining companies according to South African Mine Health and Safety Act (MHSA), 29 of 1996. Based on the study conducted by Bakotić \& Babić (2013, p. 208), it was found that workers, who work in difficult working conditions, consider the safe and healthy working environment as important factors of their job satisfaction. Therefore, the working environment is more instrumental in the change of skills shortage than terms and employment conditions in the South African gold mines.

\section{Practical Implications and Recommendations}

Today mining managers recognise the value of skilled and talented employees in driving their organisational performance. To attract, motivate and retain skilled employees, managers need to understand the magnitude of the impact of various factors contributing to staff turnover that eventually leads to the skills shortage. The results of the research suggest that about 40 percent of the change in skills shortage can be predicted by the working environment and employment conditions. As a result, the findings could be quite informative and strategic for the South African gold mining managers, whereby the managers may use these findings to improve the working environment and employment conditions in order to reduce skills shortage and comply with South African Mine Health and Safety Act 29 of 1996. Specifically, managers must ensure that employees are aware of risks and hazards in their workplace, provide adequate first aid facilities for occupational illness and injuries, workplace's temperature, light, and noise are appropriate, and maintain employer-employee good relation. If there are problems in these elements, it may place people at risks of developing tuberculosis, pneumoconiosis or silicosis (Ololade, 2012 , p. 9) and may cause job distress and dissatisfaction. The consequences of job dissatisfaction can be absenteeism, turnover, low organisation commitment and early retirement (Aydogdu \& Asikgil, 2011). This often leads to reduced competitiveness and productivity due to loss of experienced and skilled labour force through occupational injuries and fatalities and a tainted image of the organisation (Department of Minerals and Energy Affairs 2008:5). Furthermore, mining managers must align their terms and employment conditions with the South African Basic Conditions of Employment Act (BCEA) 75 of 1997 and labour disputes must be resolved as soon as possible. People are motivated by opportunities for growth and rewards and being protected from working unreasonable hours above South African national standard of 45 hours per week.

\section{The contribution of the present study}

The contribution of the study was threefold: firstly, it expands the understanding of working environment and employment conditions in reducing skills shortage, Secondly, it contributes to the growing research of skills shortage by conducting empirical tests consisting of three variables (perceived skills shortage, working environment, and employment conditions) in the gold mining context. Thirdly, the new working environment and employment conditions scales were developed which showed a good level of internal consistency of $\alpha=0.831$ and 0.891 , respectively. These findings provided evidence that the working environment and employment conditions questionnaires are reliable and valid.

\section{Limitations and Recommendations of the Study}

There are some limitations to this study. The study was based on the cross-sectional survey data, which makes it difficult to establish causal relationships resulting from the improvement of the work environment and employment conditions after a period. It could have conducted more longitudinal analyses for comparing initial scores with those obtained after corrective actions had been implemented. The study applied the non-probability sampling technique where samples were selected based on their convenience, accessibility, and proximity to the researchers. Considering its drawback of being subjected to sampling biases and systematic errors, this may limit the generalisability of the results to other sectors of the mining industry. Lastly, the research framework used two predictors (working environment and employment conditions) which managed to explain 39.98 percent variation in perceived skills shortage suggesting that there were some controlled or omitted predictors in this model. This is a sign of future research that will add other predictors in the model in order to improve $\mathrm{R}^{2}$.

\section{Acknowledgments}

This research was partially supported by the National Research Foundation of Nelson Mandela University in South Africa. Our gratitude goes to the management of three mines for allowing us to conduct an empirical study, 
participants who honestly and willingly answered the questionnaires, and university statistician for his assistance in interpreting the data of this study. Lastly but not least, we would like to thank ourselves in ensuring that this paper conforms with the standard layout of this journal.

\section{References}

Al Mamun, C. A., \& Hasan, M. N. (2017). Factors affecting employee turnover and sound retention strategies in business organisation: a conceptual view. Problems and Perspectives in Management, 15(1), 63-71. https://doi.org/10.21511/ppm.15(1).2017.06

Al-Anzi, N. M. (2009). Working environment and its impact on employee performance. Unpublished Master's Dissertation. Malaysia: Open University of Malaysia.

Antin, A. (2013). The South African Mining Sector: An Industry at a Crossroads. Economy Report South Africa, December.

Argyrous, G. (2011). Statistics for research. London: Sage.

Awases, M., Gbary, A., Nyoni, J., \& Chatora, R. (2004). Migration of health personnel in six countries: A synthesis report. Brazzaville: World Health Organisation, Regional Office for Africa.

Aydogdu, S., \& Asikgil, B. (2011). An empirical study of the relationship among job satisfaction, organisational commitment and turnover intention. International Review of Management and Marketing, 1(3), 43-53. Retrieved from https://pdfs.semanticscholar.org/604e/1921d4bb13d9dcc3427d67947aaee2063052.pdf

Bakotić, D., \& Babić, T. (2013). Relationship between working conditions and job satisfaction: The case of Croatian Shipbuilding Company. International Journal of Business and Social Science, 4(2), 206-213, Retrieved from http://www.ijbssnet.com/journals/Vol_4_No_2_February_2013/22.pdf

Barnard, B. (2012). Fairness and unilateral change of employment conditions. Unpublished Master's dissertation. Potchefstroom: North West University.

Barnow, B. S., Trutko, J., \& Lerman, R. 1998. Skill mismatches and worker shortages: The problem and appropriate responses. Washington (D.C): Urban Institute Policy Memorandum prepared for the U.S. Department of Labour.

Bernerth, E. B., \& Aguinis, H. (2016). A critical review and best-practice recommendations for control variable usage. Personnel Psychology, 69, 229-283. https://doi.org/10.1111/peps.12103

Bohlmann, H. R., Dixon, P. B., Rimmer, M. T., \& Van Heerden, J. H. (2014). The impact of the 2014 Platinum mining strike in South Africa: An economy-wide analysis. Economic Research Southern Africa, Working Paper 478, November.

Chew, J., \& Chan, C. A. (2008). Human resource practices, organisational commitment and intention to stay. International Journal of Manpower, 29(6), 503-522, https://doi.org/10.1108/01437720810904194

Colley, P. (2005). A career and life in mining: What needs to be done? Paper presented to the Sustainable Development 2005 Conference of the Minerals Council of Australia. Australia: Alice Springs, NT.

Downing, S. M. (2004). Reliability: On the reproducibility of assessment data, Medical Education, 38 pp10061012. https://doi.org/10.1111/j.1365-2929.2004.01932.x

Emery, A. C. (2005). Good practice in emergency preparedness and response. International Council on Mining and Metals. September.

Ernst \& Young (EY). (2014). Business risks facing mining and metals 2014-2015. Global Mining and Metals Leader. London: Ernst \& Young.

Eurofound. (2010). Terms and employment conditions. Dublin: Eurofound.

Field, A. (2013). Discovering Statistics using IBM SPSS Statistics. London: SAGE.

Florea, N. V., \& Mihai, D. C. (2014). Analysing the influence of IE factors on recruitment and selection performance using Kalman Filter. Journal of Science and Arts, 4(29), 299-320. Retrieved from http://www.icstm.ro/DOCS/josa/josa_2014_4/a_03_DC_Mihai.pdf

Green, F., Machin, S. \& Wilkinson, D. (1998). The meaning and determinants of skills shortages'. Oxford Bulletin of Economics and Statistics, 60(2), 165-187. https://doi.org/10.1111/1468-0084.00093

Guchait, P., \& Cho, S. (2010). The impact of human resource management practices on intention to leave of employees in the service industry in India: the mediating role of organisational commitment. The 
International Journal of Human Resource Management, 21, 1228-1247. https://doi.org/10.1080/09585192.2010.483845

Jauhar, J., \& Yusof, Y. M. (2011). Brain drain: Propensity to leave by Malaysian professionals. International Journal of Innovation, Management and Technology, 2(2), 119-122, Retrieved from https://www.ijimt.org/papers/116-M491

Johari, J., Yahya, K. K., \& Omar, A. (2011). The construct validity of organisational structure scale: Evidence from Malaysia. World Journal of Management, https://www.researchgate.net/publication/265036792

Kaplan, D. (2011). South African mining equipment and related services: Growth, constraints and policy. University of Cape Town. Making the most of commodities programme (MMCP), Discussion Paper 5.

Kingsley, N. (2012). The impact of office ergonomics on employee performance: A case study of the Ghana National Petroleum Corporation (GNPC). Unpublished Master's Dissertation. Kumasi, Ghana: Kwame Nkrumah University of Science and Technology.

Landelahni Business Leaders. (2010). Fast Facts: Local mining industry mirrors global skills crisis. Landelahni Mining Research Report 2010.

Lane, A., Guzek, J., \& Van Antwerpen, W. (2015). Tough choices facing the South African mining industry. Journal of South African Institute of Mining and Metallurgy, 115(6), 471-479, https://www.platinum.org.za/Pt2014/Papers/197-Lane

Leedy, P. N., \& Ormrod, J. E. (2005). Practical research. ( $8^{\text {th }}$ ed). Upper Saddle River, New Jersey: Pearson Merrill Prentice Hall.

Malherbe, S. (2000). A perspective on the South African mining industry in the 21st Century. Cape Town: The Graduate School of Business, University of Cape Town.

Malik, M. E., Danish, R. Q., \& Munir, Y. (2012). The impact of pay and promotion on job satisfaction: Evidence from Higher Education Institutes of Pakistan. American Journal of Economics, Special Issue, 6-9. https://doi.org/10.5923/j.economics.20120001.02

Markey, R., Ravenswood, K., \& Webber, D. J. (2012). The impact of the quality of the work environment on employees' intention to quit. University of the West of England, Economics Working Paper Series, 1220.

Masia, U., \& Pienaar, J. (2011). Unravelling safety compliance in the mining industry: Examining the role of work stress, job insecurity, satisfaction and commitment as antecedents. SA Journal of Industrial Psychology, 37(1), 01-10. https://doi.org/10.1402/sajip.v37i1.937

Moraka, N. M., \& Jansen van Rensburg, M. (2015). Transformation in the South African mining industry - looking beyond the employment equity scorecard. The Journal of the Southern African Institute of Mining and Metallurgy, 116, 669-678. https://doi.org/10.17159/2411-9717/2015/v115n8a2

Msengeti, D. M., \& Obwogi, J. (2015). Effects of pay and work environment on employee retention: A study of Hotel industry in Mombasa County. International Journal of Scientific and Research Publications, 5(4), 110. http://www.ijsrp.org/research-paper-0415/ijsrp-p4077.pdf

Musingwini, C., Cruise, J. A., \& Phillips, H. R. (2012). A perspective on the supply and utilization of mining graduates in the South African context. The Southern African Institute of Mining and Metallurgy, 113(3), 937952. Retrieved from https://www.platinum.org.za/Pt2012/Papers/937-952_Musingwini.pdf

Nunnally, J. C. (1978). Psychometric theory. 2nd ed. New York: McGraw-Hill.

O’Donnell, P., \& Mirtcheva-Broderson, D. (2015). The effect of income and working conditions on job satisfaction. New Jersey: The College of New Jersey.

Ololade, O. O. (2012). Evaluation of sustainability and environmental impacts of mining in the Rustenburg region. Unpublished Doctoral thesis. Johannesburg: University of Johannesburg.

Osborne, J., \& Waters, E. (2002). Four assumptions of multiple regression that researchers should always test. Practical Assessment, Research \& Evaluation, 8(2), 1-9. Retrieved from https://pareonline.net/getvn.asp? $=2 \& v=8$

Pallant, J. (2010). SPSS survival manual: A step by step guide to data analysis using SPSS (4th ed.). Australia: Allen \& Unwin Book Publishers.

Peek, P., Fenard, F., Gantes, P., \& Theiler, C. (2008). Skills shortages in the global oil and gas industry: How to 
close the gap. Geneva: The Centre de Recherches Entreprises et Sociétés (CRES).

Potter, P., Deshields, T., Divanbeigi, J., Berger, J., Cipriano, D., Norris, L., \& Olsen, S. (2010). Compassion fatigue and burnout: Prevalence among oncology nurses. Clinical Journal of Oncology Nursing, 14(5), E56-E62. https://doi.org/10.1188/10.CJON.E56-E62

Ram, P., \& Prabhakar, G. V. (2011). The role of employee engagement in work-related outcomes. Interdisciplinary Journal of Research in Business, 1(2), 47-61. https://www.researchgate.net/publication/260319251

Rasool, F., Botha, C. J., \& Bischoff, C. A. (2012). Push and pull factors in relation to skills shortages in South Africa. The nature, extent and effect of skills shortages on skills migration in South Africa. SA Journal of Social Sciences, 30(1), 11-20. https://doi.org/10.1080/09718923.2012.11892978

Research Focus. (2007). Research into the fundamental unit standards required for the qualifications in hard rock underground mining (NQF levels 2 and 3). Draft Report to the Mining Qualifications Authority.

Rumman, M. A. A., Jawabreh, O. A. A., Alhyasat, K. M. K., \& Hamour, H. M. J. (2013). The impact of work environment on the average of job turnover in five-star hotels in Al-Aqaba City. Business Management and Strategy, 4(2), 111-128. https://doi.org/10.5296/bms.v4i2.4020

Singh, G. (2007). Environmental concerns of coal mining: Broad view in Indian context. Dhanbad: Indian School of Mines University, Centre of Mining Environment, 52.

Skjerve, T., \& Simeo, E. (2018). A balancing act: Describing skills acquired in the workplace. Virke - The Enterprise Federation of Norway.

Tabachnick, B. G., \& Fidell, L. S. (2019). Using Mulitvariate Statistics. 7th ed. Boston: Pearson Education, Inc.

Tshele, L., \& Agumba, J. N. (2014). Investigating the causes of skills shortages in South African construction industry: a case of artisans. TG59 'People in Construction' Conference Port Elizabeth.

Van Jaarsveld, M. I. (2008). Contract in employment: Weathering storms in mixed jurisdictions? Some comparative thoughts. Electronic Journal of Comparative Law, 12(1). Retrieved from https://www.ejcl.org/121/art121-26.pdf

Van Voorhis, C. W., \& Morgan, B. (2007). Understanding power and rules of thumb for determining sample sizes. Tutorials in quantitative methods for Psychology, 3(2), 43-50. https://doi.org/10.20982/tqmp.03.2.p043

Vermaak, A. (2010). Strategic approach to skills development and staff retention. Port Elizabeth: Nelson Mandela Bay Municipality, $62^{\text {nd }}$ AMEU Convention 2010.

Webb, M. (2018). Gold Fields and NUM sign formal agreement ending South Deep strike. Mining Weekly, $18^{\text {th }}$ December.

Welman, J. C., Kruger, S. J., \& Mitchell, B. (2005). Research methodology. $3^{\text {rd }}$ edition. Cape Town: Oxford University Press.

Wiskow, C., Albreht, T., \& de Pietro, C. (2010). How to create $\mathrm{n}$ attractive and supportive working environment for health professionals? Copenhagen: World Health Organisation, Policy Briefs 15.

\section{Copyrights}

Copyright for this article is retained by the author(s), with first publication rights granted to the journal.

This is an open-access article distributed under the terms and conditions of the Creative Commons Attribution license (http://creativecommons.org/licenses/by/4.0/). 